\title{
Marking a Milestone
}

\section{Hosting a Kindergarten Library Card Party}

\author{
ANMA SMITHEBRGER AND ANW WAHLISTROM
}

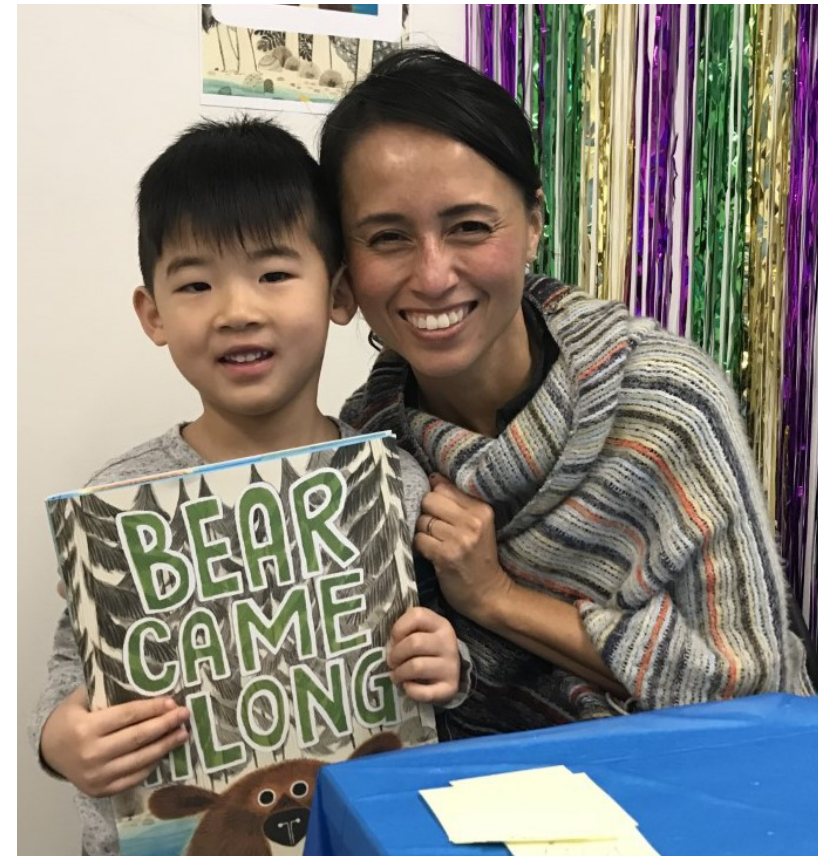

Author LeUyen Pham and Theo at a meet and greet after the presentation.
$\mathrm{T}$ ake one Caldecott Honor winner and add scores of kindergarteners. Throw in an effort to sign up more library users. Toss in a bunch of enthusiastic volunteers. That's the recipe for Ramsey County (MN) Library's (RCL) recent Kindergarten Library Card Party.

It's a program that has been running since 2008, starting humbly as a partnership between the Friends of the Ramsey County Libraries and the Junior League of St. Paul. The latter, a local women's nonprofit organization focusing on volunteerism, was interested in developing a program where they could put books into the hands of kindergarteners.

After brainstorming how we could collaborate, along with our natural desire to grow library users, we came up with the idea of a Kindergarten Library Card Party.

This year's special guest was Caldecott Honor Winner LeUyen Pham, who said, "When you first approached me about appearing at your party, I wasn't sure I wanted to accept this gig," she said. "People will really come to something like this on a Saturday? I can't believe it!”

As it turned out, we had several hundred attend our 2020 program. In fact, our annual Kindergarten Library Card party has been our most successful endeavor as a youth services team of the past ten years, and we see no end in sight!

The program has evolved and grown. Our January 2019 event featured illustrator Vanessa Brantley-Newton as our special guest. Planning for our 2020 event began as soon as the 2019 event ended.
This year we wanted LeUyen Pham, so we contacted her agent and coordinated the details. While the Friends of the Ramsey County Libraries continue to financially support this program and make it possible, we pay our special guest's speaking and travel fee with money from the Minnesota Arts and Cultural Heritage Fund. (A statewide sales tax revenue fund resulting from a state constitutional amendment to support arts, arts education, and arts access, and to preserve Minnesota's history and cultural heritage.)

We returned to party planning in October 2019, after the bustle of a busy summer reading program. Our service area includes four independent school districts, so each librarian contacted schools to discern the number of kindergarten classes and the average number of students per class. With those numbers compiled, we finalized letters to both parents and teachers and printed the number we needed, as well as addressed and

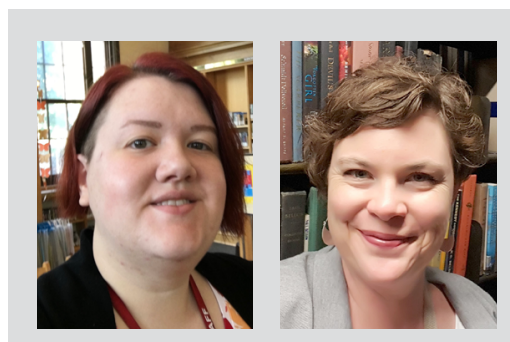

Anna Smithberger has been a children's librarian for five years. She is currently the Children's Librarian at Ramsey County (MN) Library's New Brighton branch. Ann Wahlstrom has been a children's librarian for more than thirteen years. She is currently Branch Manager at Ramsey County Library and the system's Children's Facilitator. 
stamped enough envelopes for each class to return the library card applications to RCL as easily as possible.

By the end of November, we had visited 33 schools and talked to more than 2,400 kindergarteners. We asked that the library card applications be returned by mid-December, and 1,366 applications were returned. Then we sent out the postcard invitations for the party to those who responded.

\section{Behind the Scenes}

Concurrently, the children's librarians do more behind-thescenes work to get ready for the party. First, we contract with our local independent bookstore, The Red Balloon, to sell our guest's books during an author meet and greet. We also design two library-wide scavenger hunts-one for kindergarteners to follow that takes them to important parts of the library, like the reference and circulations desks, and one for their siblings and families to do for fun. Invitations are also extended to our library board and county commissioners to attend and assist with the event; this gives them a chance to meet families and greet constituents, as well as illustrates the wonderful work their libraries are doing.

Even with our ten children's librarians on hand running the event, our library system volunteer coordinator makes sure we have enough volunteers to staff our scavenger hunt stations, and the manager of the library made sure staffing levels could handle the added traffic the party would bring.

When the party opens, participants head to a check-in table in the children's area where a librarian welcomes them and explains the event. We have all the cards at the check-in desk; the child is given the card at the end of the scavenger hunt, where they also receive a free book, purchased with money from our Friends group. At each location on the hunt, the child receives something to build their excitement and help them be great library user-such as a reusable book bag, a library card holder, and a temporary tattoo. They then finish the scavenger hunt where they are congratulated and celebrated by both staff and our library board and/or county commissioners.

After the hunt, Pham gave three presentations (and offered autographs and individual drawings) throughout the day to accommodate the large crowds.

When we wrapped up the party, 239 kindergarteners had received their new library cards, with the remaining 1,127 to be mailed home in the coming weeks.

This event can be scaled to any library's means and needs as long as you have a few things:

- First, you need time to make connections and sell the program by visiting classrooms, time to make the cards, and time to actually have the party.

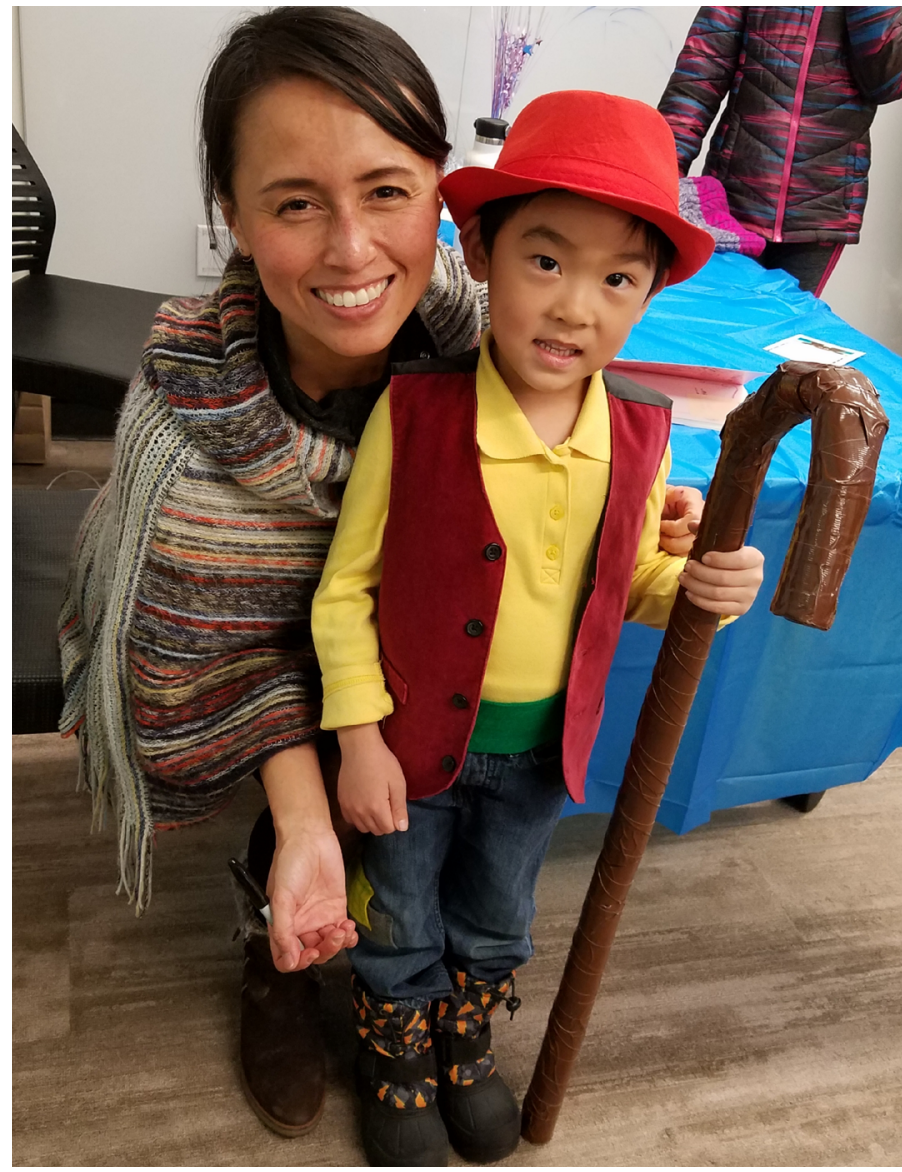

LeUyen Pham and Aaron pose together.

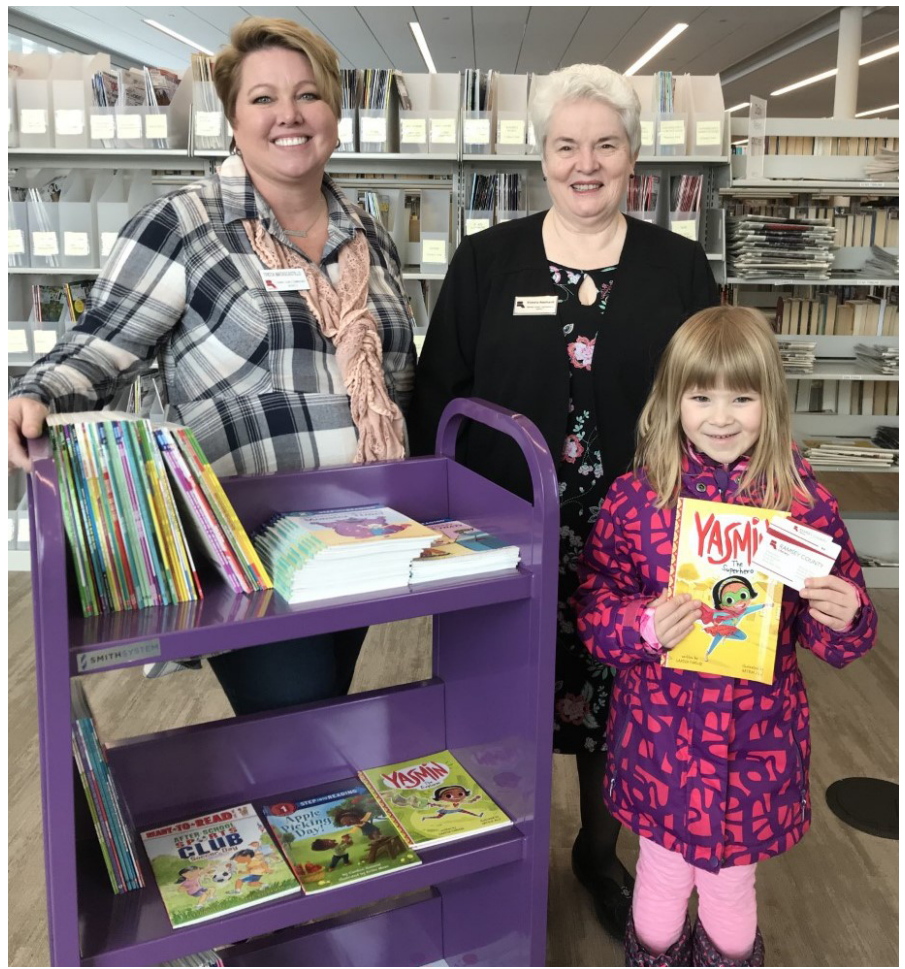

Ramsey County Board of Commissioners Trista MatasCastillo and Victoria Reinhardt pose with kindergartener Laura and her new library card. 
- School buy-in is especially valuable; having a teacher or school librarian advocate for the program greatly increases successful participation.

- Funding can also have a big say in the size and scale of your event. We are fortunate to have funding from both our Friends of the Ramsey County Library and the Minnesota Arts and Cultural Heritage Fund, but you could certainly run this program with any (or no!) dollar amount.

- You also need something to make the day special, such as a guest author and presentation. It could also be as simple as a photo booth with a butcher paper background and props.

Beyond issuing library cards to thousands of kindergarteners, what have we gained from this program? Getting a library card and going to the party has become an important milestone for kids and their families. We consistently hear how excited the kids are to get their own cards and attend a special party.

Also, through our partnership with our schools, we reach families who may never come to the library. Once here, we can introduce the whole family to the library's many resources.

We've also built a community touchstone across our service area so that all our children have this shared experience of being visited by a librarian and being told about the doors a library card can open for them.

Our Kindergarten Library Card Party can be an amazing milestone in a child's school career. Through the hard work of our amazing team, we are reaching children through partnerships with our local schools and making sure all of them have access to the resources their local public libraries can provide. \&

Pandemic Publishing — continued from page 23

Rabb, Ben. The Spooky Shallow Cough. Illus. by Brittany Cyk. 2020. 12p., www.spookyshallowcough.com

Rim, Nicole. King COVID and the Kids Who Cared. 2020. 36p., www.nicolerim.com/kidswhocared.html

Rosado, Javier and Fernandez, Tatiana. The Germ That Wears a Crown: A Story About the Coronavirus. Illus. by Jodi Slade. Florida State University Center for Child Stress \& Health, 2020. 18p., http://fsustress.org/ebook.html

Ross, Michael. I Love You: Helping Children Fight COVID-19. Illus. By Bruno Iradukunda. NABU, 2020. 21p., www.nabu.org/covid19

Samatte, Sandra. Nuttah \& Kitchi. Illus. By Julian Grafenauer. Canada, 2020. 15p., www.flipsnack.com/4canoessample /nuttah-kitchi.html

The Sisters Avendaño. The Big Alone: A Book for Kids Everywhere in the Age of Social Distancing. 2020. 48p., www.thebigalone.com

Stryker, Lacy and Stryker, Ace. Has Anyone Seen Normal: A Coronavirus Tale. 2020. 25p., https://stryker.fm/normal

Tedder, Charity. A Message from Corona. Illus. by Leighton Noyes. London, 2020. 18p., https://drive.google.com /file/d/1FevOhksly48LpU06slikMd1C0wArYyrF/view

Various contributors. Tomorrow: A Children's Book about CO$V I D-19$. Illus. by various artists. 2020. 11p., https://drive
.google.com/file/d/1H5ysOzOUDU5N5_K3SAobKZXYe2 BpOlIa/view

Watts, Annis. Piperpotamus Learns about Coronavirus. 2020. 11p., www.exeter.ac.uk/media/universityofexeter /medicalschool/documents/Piperpotamus_learns _about_Coronavirus.pdf

Watts, Molly. Dave the Dog is Worried about Coronavirus: A Nurse Dotty Book. Illus. by the author. 2020. 28p., https://nursedottybooks.com/dave-the-dog-is-worried -about-coronavirus-2/

Williams, Athol. Okay and the Virus. Illus. By Taryn Lock. South Africa, 2020. 25p., www.theartpressbooks.com /product-page/oaky-and-the-virus

Yen, Shu-Chen Jenny. Something Strange Happened in My City: A Social Story About the Coronavirus Pandemic for Children. Illus. by Glopo JCCreation and Art Center. California State University, 2020. 35p., https://social storycenter.com/english/

Yumi. Rainbows in Windows: A Book About Big Imaginations, Big Feelings, and Sheltering in Place During a Pandemic. Illus. by Karo Oh. 2020. 19 p., https://helloyumi.com /coronavirus-children-book

Zielonka, Polly. What is Coronavirus?: A Simple Explanation for Young Children. Illus. by Meghan Furey. 2020. 10p., https://pollyzielonka.wordpress.com/what-is -coronavirus \& 